Z Badań nad Książką i Księgozbiorami Historycznymi 2019. T. specjalny: Dla Niepodległej The Studies into the History of the Book and Book Collections 2019. Special issue: For an Independent Poland

ISSN 1897-0788, e-ISSN 2544-8730

www.bookhistory.uw.edu.pl

Bogumiła Warząchowska

Uniwersytet Śląski w Katowicach

bogumila.warzachowska@us.edu.pl

ORCID 0000-0002-0095-183X

\title{
„Roczniki Towarzystwa Przyjaciół Nauk na Śląsku” (1929-1938) źródłem do badań życia naukowego i kulturalnego na Górnym Śląsku
}

\begin{abstract}
"The Annals of the Society of Friends of Science in Silesia" as a source for research on cultural life in Upper Silesia

"The Annals of the Society of Friends of Science in Silesia" appeared in the years 1929-1938, as the journal of Society of Friends of Science in Silesia, established in 1920 in Katowice. The purpose of journal was to conduct scientific research on the history and present of Silesia. In the six volumes of the periodical, thanks to authors such as: Wacław Olszewicz, Konstanty Prus and Emil Szramek, scientific, educational, social and economic activity of this region was documented. The content analysis of individual volumes has shown that "The Annals of the Society of Friends of Science in Silesia" are an irreplaceable source of knowledge about the development of scientific and cultural life and its initiators in Upper Silesia during the Second Polish Republic. Therefore, they contribute significantly to the research on the nation's cultural heritage.
\end{abstract}

Key words: "The Annals of the Society of Friends of Science in Silesia" - Society of Friends of Science in Silesia - periodicals in the Second Polish Republic - cultural life in Upper Silesia. Słowa kluczowe: „Roczniki Towarzystwa Przyjaciół Nauk na Śląsku” - Towarzystwa Przyjaciół Nauk na Śląsku - czasopisma w okresie II Rzeczpospolitej - życie kulturalne na Górnym Śląsku.

„Z Badań nad Książką i Księgozbiorami Historycznymi” - Udział zagranicznych recenzentów w ocenie publikacji; Stworzenie anglojęzycznej wersji wydawniczej publikacji; Digitalizacja tomów archiwalnych rocznika w celu zapewnienia otwartego dostępu do nich przez Internet oraz wdrożenie i utrzymanie cyfrowej platformy redakcyjnej - zadanie finansowane w ramach umowy nr 653/P-DUN/2019 ze środków Ministra Nauki i Szkolnictwa Wyższego przeznaczonych na działalność upowszechniającą naukę. 


\section{Wprowadzenie}

Okres międzywojenny był szczególnym czasem dla Górnego Śląska, zwłaszcza po przyłączeniu części jego obszarów do Polski. Obok upowszechniania dziejów tych ziem pojawiła się potrzeba naukowego opracowania losów jej mieszkańców. Dla wielu Ślązaków ważnym zadaniem stało się propagowanie wiedzy o historii Śląska, jego kulturze, literaturze, bogatych tradycjach i języku polskim. Istotną rolę w budzeniu świadomości narodowej Ślązaków odegrali badacze przeszłości tego regionu, skupieni wokół Towarzystwa Przyjaciół Nauk na Śląsku (TPNŚ) i zaangażowani w wydawanie jego organu prasowego, jakim były „Roczniki Towarzystwa Przyjaciół Nauk na Śląsku” (RTPNŚ).

Celem artykułu jest przedstawienie pola badawczego na podstawie zawartości „Roczników” od pierwszego numeru do zakończenia edycji przerwanej wybuchem II wojny światowej. Organ prasowy TPNŚ prezentował szeroki zakres problemów naukowych i kulturalnych, poczynając od dziejów Śląska poprzez biografistykę, historię sztuki, zagadnienia socjologiczne, aż po krajoznawstwo, górnictwo, przemysł i rolnictwo. W opracowaniu starano się wskazać na różnorodność poruszanych obszarów badawczych, wypełniając tym samym lukę w dotychczasowej historiografii. Aby sprostać postawionemu zadaniu zastosowano metodę historyczną i analizę źródeł.

Utworzone w $1920 \mathrm{r}$. TPNŚ ma bogatą historię, a jej korzenie sięgającą lat 60. XIX w. Historia ta swym zasięgiem wykracza daleko poza granice kraju. Przełomowym okresem dla tworzącej się organizacji był upadek powstania styczniowego i następująca po nim emigracja do krajów, w których powstawały ośrodki życia kulturalnego dla uchodźców. Jedną z takich placówek, wokół której skupiała się Polonia, była Biblioteka Polska w Rumunii utworzona w 1866 r. w Jassach, która przez szereg lat służyła Polakom jako centrum życia kulturalnego ${ }^{1}$. Założona i kierowana przez dra Jana Łukaszewskiego książnica rozwijała się dzięki zakupom i darom z wydawnictw, stowarzyszeń i osób prywatnych. Jednak z upływem lat i wraz ze zmieniającą się sytuacją polityczną w Europie liczba polskich emigrantów w Rumunii zmniejszała się, co spowodowało utratę czytelników, a tym samym wpłynęło na decyzję o likwidacji biblioteki.

Gromadzony na obczyźnie przez lata księgozbiór postanowiono przekazać na Górny Śląsk, gdzie nie było znaczącej biblioteki, ani prężnie działającego ośrodka kultury. Zbiór miał wzmocnić placówki oświatowe o literaturę polską, a tym samym przeciwdziałać germanizacji. Bibliotekę z Jass podarowano zatem Towarzystwu Literackiemu działającemu od 1892 r. w Bytomiu².

1 W. Jabłońska, Biblioteka Polska w Rumunii jej wptyw na powstanie Towarzystwa Przyjaciót Nauk na Śląsku, „Roczniki Biblioteczne” 1960, t. 4, s. 477-520.

2 W. Janota, Górnośląskie Towarzystwo Literackie (1892-1920), Katowice 2002. 
Początkowo funkcjonowała ona jako czytelnia dla wąskiej grupy inteligencji, a stopniowo rozszerzała swoją działalność na inne grupy odbiorców. Trudności finansowe ograniczyły jednak dalsze prace biblioteczne. Dlatego też dokonano reorganizacji Towarzystwa Literackiego i utworzono w 1920 r. TPNŚ3

Celem programowym Towarzystwa było ożywienie i wspieranie polskiej nauki i sztuki na Śląsku oraz gromadzenie zabytków kultury ${ }^{4}$, a utworzenie własnego organu prasowego, jakim były RTPNŚ wzmocniło oddziaływanie organizacji. W tym miejscu warto zaznaczyć, że TPNŚ wydawało również serię monografii miast śląskich ${ }^{5}$, a także opracowało zeszyty materiałów źródłowych „Fontes”.

RTPNŚ wydawane były w latach 1929-1938. Początkowo tłoczone były w drukarni Karola Miarki w Mikołowie, a następnie w Drukarni Dziedzictwa bł. Jana Sarkandra w Cieszynie. W omawianym okresie ukazało się z nieregularną częstotliwością sześć tomów o łącznej objętości 2460 stron. Na żadnym $\mathrm{z}$ wydanych tomów nie odnotowano ceny jednostkowej. Od początku osobą odpowiedzialną za powstanie i rozwój pisma był ks. Emil Szramek (18871942), który doświadczenie redakcyjne zdobył wydając przez kilka lat popularnonaukowy kwartalnik „Głosy z nad Odry”. Periodyk ukazywał się w latach 1918-1924 wydawany w Opolu przez Towarzystwo Oświaty im. św. Jacka 7

Główny zrąb „Roczników” stanowią artykuły, które od piątego tomu nazwane zostały Rozprawami. Również od piątego tomu utworzono nowy dział:

3 J. Łuka, Z dziejów Towarzystwa Przyjaciót Nauk na Śląsk, RTPNŚ 1929, t. 1, s. 7; J. Dziwoki, Towarzystwo Przyjaciót Nauk na Śląsku. Kroniki śląskiego życia umysłowego, [w:] Katowice w kulturze pogranicza. Rola Katowic w kulturze i nauce, red. nauk. A. Barciak, Katowice 2012, s. $232-242$.

4 Statut Towarzystwa Przyjaciół Nauk na Ślasku, RTPNŚ 1938, t. 6, s. 511.

5 Monografie miast Śląskich: Powiat świętochtowicki. Monografia, oprac. przez komitet red. pod przewod. starosty świętochłowickiego T. Szalińskiego, Katowice 1931, Monografie Towarzystwa Przyjaciół Nauk na Śląsku, 1; K. Prus, Z przeszłości Mikołowa i jego okolicy, Mikołów 1932, Monografie Towarzystwa Przyjaciół Nauk na Śląsku, 2; L. Musioł, Pszczyna. Monografia historyczna, Katowice 1936, Monografie Towarzystwa Przyjaciół Nauk na Śląsku, 3; A. Koziołek, Knurów i Krywatd. Kronika na tle historii ziemi gliwickiej, Katowice 1937, Monografie Towarzystwa Przyjaciół Nauk na Śląsku, 4.

6 Zeszyty materiałów źródłowych: Historia residentiae et templi Societatis Jesu Piekarii (1678-1716), Katowice 1932, Fontes - Towarzystwo Przyjaciół Nauk na Śląsku, 1; Staropolskie teksty z protokolarza miasta Woźniki w województwie śląskim 1521-1750, wyd. i wstępem opatrzył L. Musioł, Katowice 1936, Fontes - Towarzystwo Przyjaciół Nauk na Śląsku, 2; Akta wizytacji dekanatów bytomskiego i pszczyńskiego dokonanej w 1598 z polecenia Jerzego kardynała Radziwitła, biskupa krakowskiego, wyd., wstępem i objaśnieniami zaopatrzył M. Wojtas, Katowice 1938, Fontes - Towarzystwo Przyjaciół Nauk na Śląsku, 3; Księga protokołów konwentów pastorskich ziemi pszczyńskiej (1588-1628), oprac. J. Bańka, Katowice 1938, Fontes - Towarzystwo Przyjaciół Nauk na Śląsku, 4; Wędrynia. Jedna ze wsi beskidzkich w pow. cieszyńskim. Jej dzieje i źródła historyczne z Archiwum Zamkowego w Cieszynie, wyd. i wstępem opatrzył F. Popiołek, Katowice 1938, Fontes - Towarzystwo Przyjaciół Nauk na Śląsku, 5.

7 J. Reiter, Towarzystwo Oświaty na Ślasku im. św. Jacka, Opole 1968, s. 34-40. 
Wieczory dyskusyjne Towarzystwa Przyjaciół Nauk na Śląsku. We wszystkich „Rocznikach” umieszczono stałe działy: Wspomnienia pośmiertnie (informujące o osobach zmarłych w ostatnim czasie, a zasłużonych dla regionu) oraz kolejny dział zatytułowany Rozbiory $i$ sprawozdania. Całość przedstawionego w „Rocznikach” materiału zamyka obszerny dział Z umysłowego życia Śląska, będący kroniką naukowej, kulturalnej i oświatowej pracy na Śląsku. To właśnie te działy staną się elementem przeprowadzonej analizy zawartości, dzięki czemu ukazany zostanie rozwój życia umysłowego, naukowego i kulturalnego na Górnym Śląsku w okresie II Rzeczpospolitej oraz zostaną zaprezentowani twórcy i badacze oraz ich działalność.

Ogółem w „Rocznikach” opublikowano 284 prace napisane przez 101 autorów. Najbardziej płodnym twórcą okazał się E. Szramek, który opublikował 70 tekstów, Wincenty Ogrodziński 30, Wacław Olszewicz 19, Mieczysław Łączkowski 12, Tadeusz Dobrowolski osiem, Ludwik Musioł i Franciszek Popiołek po siedem pozycji, Roman Lutman i Stanisław Warcholik po sześć. Łącznie tych dziewięciu autorów opublikowało 165 prac. Natomiast pozostali - w liczbie 92 - przygotowali 119 tekstów, w tym po kilka recenzji lub pojedyncze artykuły. Najbardziej zaangażowany w tworzenie periodyku był E. Szramek.

Ciężar wydawania „Roczników” spoczywał głównie na barkach E. Szramka $\mathrm{i}$ to jemu w znacznej mierze zawdzięczamy dokumentowanie i promowanie dorobku naukowego i kulturalnego Śląska. „Roczniki” stały się miejscem dojrzałego pisarstwa E. Szramka. Z Przedmowy do obszernej biografii o śląskim kapłanie czytamy:

Ks. dr Emil Szramek był człowiekiem wyjątkowej kultury i głębokiej wiedzy. Wielkie swe zdolności rozwijał stale mrówczą pracą w takim stopniu, że wyrósł na osobowość wybitną w skali krajowej w Polsce międzywojennej [...] jako badacz historii i kultury, jako kolekcjoner dzieł sztuki, myśliciel, redaktor, duszpasterz, więzień obozów koncentracyjnych i niestrudzony obrońca ludu'

Zaangażowany na wielu polach życia kościelnego i świeckiego, umiejętnie łączył pracę duszpasterską z działalnością naukową, o czym świadczy bogata i różnorodna bibliografia licząca 186 pozycji9.

Ta wybitna postać była inspiracją do zorganizowania konferencji ${ }^{10}$, sympozjów ${ }^{11}$ i spotkań. Stała się też przedmiotem znacznej liczby publikacji ${ }^{12}$, któ-

8 H. Bednorz, J. Bańka, Życie i działalność ks. Emila Szramka 1887-1942, Katowice 1966, s. 5.

9 Tamże, s. 203-211.

10 Nowe oblicza bł. Emila Szramka, pod red. K. Heskiej-Kwaśniewicz i J. Myszora, Katowice 2003.

$11 \quad$ K. Heska-Kwaśniewicz, Ks. dr E.Szramek - życie i działalność (zarys), [w:] Ks. dr Emil Szramek. Działalność i dzieła. Materiały posesyjne, red. J. Malicki i J. Śliwiok, Katowice 1994, s. 9-14.

12 O ks. E. Szramku zob. M. Fazan, Emil Szramek - organizator życia naukowego na Ślasku w okresie międzywojennym, [w:] Kronika Katowic. T. 4, Katowice 1993, s. 57-73; K. Tałuć, 
re odzwierciedlają wkład tworkowskiego kapłana w życie umysłowe Śląska. $\mathrm{W}$ tekstach wyeksponowano jego zainteresowania i pasje związane m.in.: ze sztuką sakralną ${ }^{13}$ i turystyką ${ }^{14}$. W wielu pracach udokumentowano także męczeńską śmierć błogosławionego kapłana ${ }^{15}$.

\section{Artykuły i rozprawy w „Rocznikach Towarzystwa Przyjaciół Nauk na Śląsku"}

Podstawowy trzon struktury „Roczników” stanowią teksty, których opublikowano 72, napisane przez 41 autorów. Największy udział twórczy miał redaktor naczelny, aż 17 z nich wyszło spod pióra E. Szramka. T. Dobrowolski opublikował pięć prac, a L. Musioł i F. Popiołek po trzy . Z kolei Zofia Birkenmajerowa, ks. Emanuel Grim, Stanisław Kobyliński, W. Ogrodziński, W. Olszewicz, S. Warcholik oraz Jan Wypler przygotowali po dwie publikacje. Pozostałych 30 autorów złożyło po jednym artykule.

Od początku ukazywania się pisma E. Szramkowi zależało na drukowaniu rozpraw naukowych, dlatego we wstępie do pierwszego tomu wyraził swoje oczekiwania:

Artykuły pomieszczane w „Rocznikach”, stanowią wyraz poglądów swych autorów, za które

Towarzystwo nie odpowiada. Odpowiada ono jednak za ich myśl przewodnią, którą jest bezstronne naukowe oświetlenie przeszłości czy teraźniejszości tej odwiecznej polskiej dzielnicy, o której nauka polska dotychczas należycie nie pamiętała, a która umiała bohatersko walczyć o powrót do Ojczyzny ${ }^{16}$.

Zgodnie z redakcyjnymi oczekiwaniami łamy „Roczników” w zdecydowanej części zostały wypełnione tekstami historycznymi i biograficznymi, uzupełnionymi o artykuły poruszające zagadnienia społeczne, literackie, gospodarcze, administracyjne, a także z zakresu sztuki i etnografii.

Ks. dr Emil Szramek jako redaktor i autor prac publikowanych na łamach „, Gtosów znad Odry” $i$ „,Roczników Towarzystwa Przyjaciót Nauk na Ślasku”, „Annales Silesiae” 1998, t. 28, s. 43-58; J. Myszor, Ks. Emil Szramek-kapłan diecezji wrocławskiej (1911-1922), „Ziemia Śląska” 2001, t. 5, s. 73-80.

13 H. Pyka, Mecenat artystyczny Księdza Emila Szramka w Parafii Mariackiej w Katowicach, „Śląskie Studia Historyczno-Teologiczne” 1992-1993, t. 25-26, s. 307-316; J. Tofilska, Parafia Mariacka w Katowicach. Historia jak witraż, Katowice 2010.

14 A. Szanecka, Pasje turystyczne ks. Emila Szramka, „Wiadomości Archidiecezjalne” 1996, nr 8, s. 382-384.

15 J. Myszor, Dlaczego zginąt ks. Emil Szramek, [w:] Victor-quia Victima. Ksiądz Emil Szramek (1887-1942). Praca zbiorowa, pod red. E. Szczotoka i A. Liskowackiej, Katowice 1996, s. 59-68; tenże, Stuga Boży ks. Emil Szramek - proces beatyfikacyjny Męczenników II wojny światowej. Nowe pytania i odpowiedzi. Edycja tekstów źródłowych, „Śląskie Studia Historyczno-Teologiczne” 1997, t. 30, s. 249-271; tenże, Stuga Boży ks. Emil Szramek (1887-1942), [w:] Męczennicy za wiarę 19391945, red. W.M. Moroz, A. Datko, Warszawa 1996, s. 95-100.

16 [Wstęp], RTPNŚ 1929, t. 1, s. [5]. 


\section{Opracowania historyczne}

Najliczniejszą grupę (bo aż 27 tekstów) stanowią prace historyczne. Znamienny jest fakt, że tekstem otwierającym pismo jest artykuł zatytułowany Z dziejów Towarzystwa Przyjaciót Nauk na Śląsku17, który wprowadza czytelnika w początki organizacji, nakreślając jej bogatą historię, udokumentowaną materiałem źródłowym. Z kolei Franciszek Bujak w swoim artykule przypomina, że badania historyczne należą do głównych celów TPNŚ:

Jest rzeczą oczywistą, że [...] Śląsk nie może się obywać bez badań historycznych, nie może powierzać innym odłamom narodu, lub nawet obcym narodom, troski o spisywanie swojego «życiorysu», o zdawanie sobie sprawy ze swojego rozwoju ${ }^{18}$.

Osoby współpracujące z TPNŚ były przekonane, że historia jest podstawowym elementem kultury, bez której nie ma cywilizowanego społeczeństwa, stąd troska i potrzeba prowadzenia badań. Należy podkreślić, że również $\mathrm{S}$. Warcholik był jednym z tych badaczy, którzy sięgnęli do średniowiecznych źródeł, ukazując rolę duchowieństwa śląskiego w obronie polskości na Śląsku w XIII w. ${ }^{19} \mathrm{~W}$ artykule opublikowanym w kolejnym numerze „Rocznika” analizował politykę Kazimierza Wielkiego w odniesieniu do Śląska, a co za tym idzie relacje z Czechami i Niemcami ${ }^{20}$. Rozpatrywał tu także rolę Kościoła w pielęgnowaniu polskich tradycji i współpracę ze Stolicą Apostolską.

Liczne wskazania potwierdzające polskość Śląska odnajdujemy również w pracach E. Szramka, który ukazywał m.in. znaczenie i rolę Kościoła w organizowaniu szkolnictwa na Górnym Śląsku ${ }^{21}$, gdzie szerzono polską kulturę. Według autora szkoły te reprezentowały zróżnicowany poziom, jednak fakt ich zakładania i funkcjonowania był, jak na ówczesne warunki, dużym osiągnięciem. W artykule Szramek dokonał przekrojowej analizy szkolnictwa śląskiego począwszy od XIII w. do omówienia konkordatu z 1925 r. Nieco inny charakter badawczy ma przeprowadzona przez niego analiza rękopisu z 1464 r., w którym znajduje się zestawienie dochodów archidiakona opolskiego Marcina Linderera. Dokument ten uznany został za ,szczegółowy przyczynek do dziejów kultury rodzimej”22. Natomiast wspólna praca T. Dobrowolskiego i E. Szramka

17 J. Łuka, Z dziejów Towarzystwa Przyjaciół Nauk..., s. 1-18.

18 F. Bujak, W sprawie organizacji studiów historycznych $w$ Towarzystwie Przyjaciót Nauk na Śląsku, RTPNŚ 1930, t. 2, s. 63.

19 S. Warcholik, Duchowieństwo śląskie XIII w. w walce o jedność państwowa z Polska, RTPNŚ 1929, t. 1, s. 162-184.

20 Tenże, Polityka śląska Kazimierza Wielkiego w latach 1333-1339, RTPNŚ 1930, t. 2, s. 96118.

21 E. Szramek, Organiczny zwiazek urzędów szkolnych z kościelnymi w historycznym rozwoju na Śląku, RTPNŚ 1929, t. 1, s. 58-68.

22 Tenże, Szczegółowy (częściowy) wykaz dziesięcin archidiakona opolskiego z roku 1464, RTPNŚ 1930, t. 2, s. 271-278. 
przedstawia zarówno dzieje obrazu Matki Bożej Piekarskiej, jak też zagadnienia estetyki z perspektywy historii sztuki ${ }^{23}$. Z kolei publikacje F. Popiołka odnoszą się do zbiorów muzealnych znajdujących się w cieszyńskich placówkach kultury, takich jak: Archiwum Miejskie, Archiwum Zamkowe, Biblioteka Macierzy Szkolnej, Biblioteka Zboru Ewangelickiego, Muzeum Miejskie, Muzeum Sądowe. Nadrzędnym zadaniem tych instytucji było gromadzenie i ochrona zabytków, a w ślad za tym propagowanie kultury polskiej ${ }^{24}$. Zgromadzone obiekty i dokumenty, zwłaszcza rękopisy, F. Popiołek przedstawiał jako bezcenne źródło wiedzy historycznej dla ówczesnych i przyszłych pokoleń oraz świadectwo polskości tych terenów ${ }^{25}$. Ziemia cieszyńska stała się również obiektem zainteresowań Witolda Sahanka, który nie tylko opisał jej historię, dokumentując ilustrowaną genealogią piastowskich książąt cieszyńskich, ale także omówił postanowienia Sądu Najwyższego w Warszawie z 1930 r. ${ }^{26}$

Zagadnienia prawno-historyczne donośnie wybrzmiały w pracy Piotra Pampucha, który przeprowadził analizę sytuacji polskich chłopów na Górnym Śląsku niemal od XII w., a ostatecznie skoncentrował swoje badania na XIX-wiecznych źródłach ${ }^{27}$. Los chłopów górnośląskich mocno wpisuje się w polityczno-społeczne zależności, a jednocześnie warto podkreślić, że ta grupa społeczna kultywowała przywiązanie do polskiej tradycji. O łączności kulturowej i politycznej Ślązaków, którzy przyczyniali się do promowania Śląska i Polski poza granicami kraju, pisał ks. Józef Gawlina ${ }^{28}$. Autor, Ślązak pełniący w różnych krajach posługę duszpasterską dla Polonii, zwracał się z apelem do polskich historyków, aby współpracowali z Polonią oraz pielęgnowali kulturę i rodzime tradycje.

\section{Prace z pozostałych dziedzin wiedzy}

Redaktorzy „Roczników” zabiegali o to, aby na łamach pisma była prezentowana zróżnicowana tematyka, dlatego pozyskiwano autorów specjalistów z dziedzin takich jak: etnografia, kultura, literatura, nauki społeczne, sztuka oraz z zagadnień administracyjno-gospodarczych. Część prac stanowiły obszerne monografie wzbogacone ilustracjami i materiałem źródłowym. Jedną

23 T. Dobrowolski, E. Szramek, Obraz Matki Bożej w Opolu oraz podobne mu gotyckie wizerunki Madonny z Dzieciątkiem, RTPNŚ 1938, t. 6, s. 203-222.

24 F. Popiołek, Zbiory cieszyńskie, RTPNŚ 1930, t. 2, s. 214-225.

25 Tenże, Materialy do historii Ślaska w zbiorach cieszyńskich, RTPNŚ 1931, t. 3, s. 343-347; tenże, Kamienica Demlowska, siedziba Muzeum Miejskiego w Cieszynie, RTPNŚ 1931, t. 3, s. 348350 .

26 W. Sahanek, Spór o dobra cieszyńskie, RTPNŚ 1931, t. 3, s. 168-254.

27 P. Pampuch, Usamowolnienie i uwłaszczenie polskich chłopów górnoślaskich, RTPNŚ 1929, t. 1, s. 36-57.

28 J. Gawlina, Zastugi Ślazaków około starej Polski, RTPNŚ 1931, t. 3, s. 160-167. 
z najciekawszych była rozprawa E. Szramka Śląsk jako problem socjologiczny, w której autor odnosił się do trudnych spraw związanych z tożsamością Ślązaków. W pracy tej twierdził, że sprawa Śląska urosła do

bolesnego problemu, tak bardzo skomplikowanego, że najlepszym znawcom stosunków zdawało się czasem, że to istny węzeł gordyjski, który nie może być rozwiązany, lecz musi zostać gwałtem rozcięty ${ }^{29}$.

Rozpatrywał różne kwestie, które miały wpływ na kształtowanie się tzw. „duszy” Ślązaków i zgłębiał jej „dwuwarstwowość” w ujęciu historycznym, narodowym, religijnym, społecznym, politycznym i kulturowym. Z analizy tekstu wyłania się obraz Ślązaka głęboko religijnego, wokół którego nowa Polska umacniała się moralnie. Praca ta oceniona została przez ówczesnych badaczy wysoko i uznana za odważną analizę śląskiej rzeczywistości. W. Ogrodziński zaliczył ją

do rzeczy najgodniejszych poznania z ostatnich wydawnictw o Śląsku. Należy ona do tych książek, których wartość polega na pobudzeniu do przemyślenia ponownego załatwionych pozornie zagadnien' ${ }^{30}$.

Opracowania równie trudnego i kontrowersyjnego problemu podjął się Józef Żółtaszek w artykule Dzikie kopalnictwo węgla na Górnym Śląsk ${ }^{31}$, w którym poruszył zagadnienia społeczne i prawne, łącząc je z geograficznymi i gospodarczymi. Bezrobocie, pogarszające się warunki życia, wysokie ceny węgla sprawiły rozprzestrzenienie się nielegalnego kopalnictwa, zwanego „biedaszybami”. Węgiel wydobywany z dzikich szybów zapewniał egzystencję bezrobotnym górnikom i innym pozostającym bez pracy, jednak moralnie i prawnie zjawisko to zostało ocenione negatywnie. Innym zagadnieniem nurtującym Ślązaków były sprawy społeczno-gospodarcze, poruszone przez W. Olszewicza w pracy Śląsk $i$ Battyk ${ }^{32}$. W tekście tym autor uświadamiał Ślązakom korzyści handlowe i społeczne wynikające z budowy portu w Gdyni, a także podkreślał pożytek płynący z tego dla Śląska i Polski. Z kolei Regina Danysz-Fleszarowa w pracy Wspótczesne badania geologiczne na Górnym Śląsku $u^{33}$ wskazała na konieczność prowadzenia tego typu badań na obszarach Śląska, zwłaszcza w kontekście złóż węgla kamiennego i właściwego wykorzystania bogactw naturalnych.

Ważne miejsce na łamach „Roczników” zajmują prace etnograficzne dotyczące zabytkowych kościołów ziemi cieszyńskiej ${ }^{34}$ oraz tańców i pieśni

\footnotetext{
29 E. Szramek, Ślask jako problem socjologiczny, RTPNŚ 1934, t. 4, s. 22.

30 Cyt. za H. Bednorz, J. Bańka, Życie i dziatalność ks. Emila Szramka..., s. 150.

31 J. Żółtaszek, Dzikie kopalnictwo węgla na Górnym Ślasku, RTPNŚ 1936, t. 5, s. 282-299.

32 W. Olszewicza, Śląsk i Bałtyk, RTPNŚ 1929, t. 1, s. 110-124.

33 R. Danysz-Fleszarowa, Wspótczesne badania geologiczne na Górnym Ślasku, RTPNŚ 1931,

34 J. Londzin, Kościoły drewniane na Śląsku Cieszyńskim, RTPNŚ 1929, t. 1, s. 19-35.
} t. 3, s. 356-368. 
górnośląskich ${ }^{35}$. Inicjatywy tworzenia instytucji kultury na Górnym Śląsku zostały udokumentowane w pracach T. Dobrowolskiego, w których autor odnosił się do początków działalności Muzeum Śląskiego w Katowicach ${ }^{36}$. Natomiast R. Lutman ogłosił artykuł wskazujący na potrzebę utworzenia biblioteki publicznej w Katowicach, a także scharakteryzował ważniejsze dzieła literackie z Górnego Śląska ${ }^{37}$. Inne prace odnosiły się do czasopiśmiennictwa górnośląskiego, promocji tytułów i publiczności czytelniczej. Mieczysław Gładysz w artykule Polskie czasopisma dla dzieci i młodzieży na Śląsku ${ }^{38}$ dokonał przeglądu i charakterystyki wydawanych periodyków. Z kolei Ludwik Brożek i Oskar Michejda w pracy Powojenna prasa polska na Śląsu Cieszyńskim podkreślili znaczącą liczbę tytułów czasopism ukazujących się na Śląsku Cieszyńskim oraz popularność i poczytność prasy wśród mieszkańców tych ziem ${ }^{39}$.

\section{Materiały biograficzne}

Kulturę Śląska promowano na łamach „Roczników” również za pomocą tekstów biograficznych, w których scharakteryzowano 24 postacie zasłużone dla regionu. Najliczniejsza grupa opracowanych biogramów dotyczyła duchownych, którym poświęcono 10 not; następnie literatów i prawników (po trzy), dziennikarzy, lekarzy i działaczy społecznych (po dwie); pozostałe zaś dwa biogramy dotyczyły bibliotekarza i inżyniera górnictwa. Teksty przybrały w większości formę wspomnień pośmiertnych, które regularnie zamieszczano w każdym numerze „Roczników”. Także w dziedzinie biografistyki najwięcej tekstów przygotował E. Szramek. Na uwagę zasługuje, z racji wielkiego wkładu w kulturę Śląska, opracowanie Ks. Norbert Bonczyk. Homer górnośląski i poeta walki kulturalnej. Studium historyczno-literackie, $w 50$ lat po pierwszym wydaniu ,,Starego Kościoła Miechowskiego " ${ }^{40}$, w którym przedstawiono życiorys kapłana, bibliografię jego prac oraz omówiono najważniejsze dzieła, jak Górę Chetmską i Stary Kościót Miechowski.

\footnotetext{
35 S. Walis, O tańcach górnoślaskich, RTPNŚ 1929, t. 1, s. 185-198.

36 T. Dobrowolski, Oddziat sztuki i Muzeum Śląskiego w Katowicach, RTPNŚ 1929, t. 1, s. 90109; tenże, Działalność Muzeum Ślaskiego w Katowicach, RTPNŚ 1930, t. 2, s. 170-208.

37 R. Lutman, Biblioteka Sejmu Śląskiego w Katowicach, RTPNŚ 1930, t. 2, s. 209-213; tenże, Regionalna Polska literatura historyczna na Górnym Ślasku, RTPNŚ 1929, t. 1, s. 208-221.

38 M. Gładysz, Polskie czasopisma dla dzieci i młodzieży na Śląsu, RTPNŚ 1931, t. 3, s. $303-321$.

39 L. Brożek, O. Michejda, Powojenna prasa polska na Śląsku Cieszyńskim, RTPNŚ 1934, t. 4, s. $217-230$.

40 E. Szramek, Ks. Norbert Bonczyk. Homer górnoślaski i poeta walki kulturalnej. Studium historyczno-literackie, w 50 lat po pierwszym wydaniu ,,Starego Kościoła Miechowskiego”, RTPNŚ 1930, t. 2, s. 1-62.
} 
W tym samym tomie ukazał się biogram opracowany przez E. Szramka Dr med. Józef Rostek. Życiorys a zarazem przyczynek dziejów narodowego odrodzenia Ślask $a^{41}$. Autor przedstawił sylwetkę pierwszego polskiego medyka, reprezentanta rodzimej inteligencji w Raciborzu, zasłużonego działacza plebiscytowego, lekarza powstańczego oraz współtwórcę „Nowin Raciborskich”, pisma ukazującego się w latach 1889-1921 w Opolu. W kolejnym tomie redaktor RTPNŚ zaprezentował sylwetkę ks. Jana Kapicy, Ślązaka zaangażowanego w sprawę narodową, wybitnego myśliciela, wprawnego kaznodzieję, znakomitego społecznika i aktywisty. Autor przybliżył ją w opracowaniu Ks. Jan Kapica. Życiorys a zarazem fragment historii Górnego Ślaska ${ }^{42}$, w którym życie bohatera ukazano w trzech odsłonach:

1.miłość do narodu polskiego, którego synem się czuł, 2. sprawiedliwość i szacunek dla narodu niemieckiego, którego współobywatelem był, 3. lojalność sumienna względem państwa, którego poddanym by $1^{43}$.

E. Szramek dał dowód szczególnej sympatii i przyjaźni do mikołowskiego proboszcza, z którym połączyło go przywiązanie do ludu śląskiego. Pisał o nim: „Lud u niego zawsze miał pierwszeństwo”"44. Kolejny biogram, który wyszedł spod pióra E. Szramka, to obszerne studium historyczne zatytułowane Ks. Aleksander Skowroński. Obraz życia i pracy na tle problematyki kresów zachodnich. O A. Skowrońskim autor tak napisał:

Był tu naprawdę «solą ziemi» bo surowiznę nacjonalizmu z wielką i wyrozumiałą miłością we walnej mierze sam uchrześcijanił [...]. Jeżeli więc dla wszystkich Polaków ciekawym być musi życie tak wybitnego kapłana kresowego, to u licznych przyjaciół dochodzi wdzięczny pietyzm dla jego czcigodnej postaci o tak dobrym sercu, o złotym humorze i wyjątkowych zaletach towarzyskich ${ }^{45}$.

E. Szramek znał zasługi A. Skowrońskiego, które szczególnie ujawniły się podczas wspólnej pracy w Towarzystwie Oświaty im. św. Jacka i redagowaniu kwartalnika „Głosy znad Odry”, dlatego nie zawahał się w opracowanej biografii wzbogacić tekst kilkunastoma załącznikami z wystąpień, przemówień i odezw mikołowskiego kapłana.

Niemałe zasługi dla Śląska wniósł również ks. Józef Londzin. Jego życie i działalność zostały upamiętnione przez E. Grima w pracy Ks. Józef Londzin (8.II 1862-21.IV 1929). (Szkic biograficzny) ${ }^{46}$. J. Londzin, długoletni redaktor

${ }_{41}$ Tenże, Dr med. Józef Rostek. Życiorys a zarazem przyczynek dziejów narodowego odrodzenia Śląska, RTPNŚ 1930, t. 2, s. 142-169.

42 Tenże, Ks. Jan Kapica. Życiorys a zarazem fragment historii Górnego Śląska, RTPNŚ 1931, t. 3, s. 1-86.

43 Tamże, s. 36.

44 Tamże, s. 84.

45 E. Szramek, Ks. Aleksander Skowroński. Obraz życia i pracy na tle problematyki kresów zachodnich, RTPNŚ 1936, t. 5, s. 7.

46 E. Grim, Ks. Józef Londzin (8 II 1862-21 IV 1929). (Szkic biograficzny), RTPNŚ 1930, t. 2, s. 68-95. 
„Gwiazdki Cieszyńskiej”, pisma wydawanego w Cieszynie w latach 18511939, zasłużony dla Macierzy Szkolnej Księstwa Cieszyńskiego, angażował się w działalność na polu narodowym, społecznym, gospodarczym i politycznym, a zwłaszcza naukowym

bo celem jego prac było poza wykazaniem polskości Śląska, unaocznienie, że Śląsk to nie jakiś tam kopciuszek, ale dzielnica, która godnie stanąć może obok innych siostrzyc przy boku matki-Polski ${ }^{47}$.

Szczególną wartość naukową zachowały jego prace bibliograficzne, w których zgromadził polskie piśmiennictwo Śląska Cieszyńskiego, a także znaczące opracowania dotyczące szkolnictwa polskiego na tym terenie.

Spośród licznych prac biograficznych opublikowanych na łamach RTPNŚ, na uwagę zasługuje studium monograficzne W. Ogrodzińskiego O. Euzebiusz Franc. Stateczny przedstawiciel „Młodej Polski” w prozie Górnoślaskiej ${ }^{48}$. E. Stateczny pozostawił po sobie pokaźny dorobek, na który składają się prace filozoficzne, homiletyczne, hagiograficzne i teologiczne, a także publicystyka i beletrystyka. Według W. Ogrodzińskiego był on

najwybitniejszym przedstawicielem sztuki pisarskiej i nauki, oraz w piśmiennictwie górnośląskim, w którym jako prozaik wyróżnia się nie tylko czystością i pięknością swej polszczyzny, lecz także doprowadzeniem prozy śląskiej do poziomu współczesnej literatury polskiej $^{49}$.

Wymienione prace to nie tylko obszerne życiorysy ówczesnych uczonych śląskich. O każdej z postaci powstał biogram udokumentowany bogatym materiałem źródłowym. Uzupełnieniem ich są kilkustronicowe, często opracowane w postaci popularnej, zamieszczane w celu upamiętnienia zasług, wspomnienia pośmiertne. Najwięcej ich - ponownie - wyszło spod pióra E. Szramka. Już w pierwszym tomie „Roczników” w dziale Wspomnienia pośmiertne przybliżył on postać ks. Józefa Gregora ${ }^{50}$, tworkowskiego proboszcza, autora wielu prac naukowych dotyczących historii Śląska oraz zamieścił wspomnienie o ks. Janie Chrząszczu ${ }^{51}$, piskowickim proboszczu, wybitnym znawcy problematyki śląskiej i obrońcy polskości. Kolejne upamiętnienie poświęcił E. Szramek Antoniemu Bednarskiemu ${ }^{52}$, emerytowanemu dyrektorowi Biblioteki Raczyńskich w Poznaniu, a także redaktorowi „Nowin Śląskich”; ks. Wiktorowi Lossowi, proboszczowi pawłowickiemu, a zarazem dziekanowi żorskiemu ${ }^{53}$,

47 Tamże, s. 89.

48 W. Ogrodziński, O. Euzebiusz Franc. Stateczny przedstawiciel „Młodej Polski” w prozie Górnośląskiej, RTPNŚ 1938, t. 6, s. 7-202.

49 Tamże, s. 182.

50 Tenże, Ks. proboszcz Józef Gregor, RTPNŚ 1929, t. 1, s. 254-258.

51 Tenże, Ks. dr Jan Chrząszcz, RTPNŚ 1929, t. 1, s. 258-261.

52 Tenże, Antoni Bednarski, RTPNŚ 1931, t. 3, s. 384-385.

53 Tenże, Ks. Wiktor Loss, RTPNŚ 1934, t. 4, s. 241-248. 
historykowi, prawnikowi, teologowi i lingwiście; ks. Franciszkowi Zieglerowi ${ }^{54}$, którego nazwał: „chodzącym sumieniem duszpasterskim «in puncto» katolickiego pietyzmu dla ojczystego języka" ${ }^{55}$. Jednak spośród pośmiertnych biogramów szczególne zainteresowanie wzbudza tekst: Wspomnienie pośmiertne. Ś.P. Adam Napieralski ${ }^{56}$, który stanowi szkic monograficzny na temat działacza społecznego i polityka oddanego sprawie narodowej, a także zasłużonego wydawcy gazet, $\mathrm{m}$.in. pierwszego w języku polskim ukazującego się na Śląsku dziennika „Katolik”, wydawanego w latach 1868-1931, który redagował przez 30 lat.

Poza E. Szramkiem biogramy zamieścili również ks. Paweł Kuczka ${ }^{57}$, W.Olszewicz ${ }^{58}$, Bogusław Parczewski, S. Kobyliński ${ }^{59}$, Konstanty Wolny ${ }^{60}$ oraz Henryk Hulok ${ }^{61}$. Publikowane na łamach „Roczników” życiorysy i wspomnienia są niejednokrotnie jedynym źródłem na temat opisywanych osób dla współczesnej biografistyki, dlatego zaprezentowany materiał ma szczególną wartość badawczą.

\section{Recenzje i sprawozdania formą promocji literatury i pracy twórczej}

Promocja literatury i wskazywanie wartościowych lektur było częstym tematem wykładów i odczytów oraz spotkań zespołu redakcyjnego, o czym donoszono w regularnych sprawozdaniach. Nie dziwi więc fakt, że część RTPNŚ zajmowały recenzje i omówienia nowości wydawniczych, zwłaszcza odnoszących się do tematyki śląskoznawczej. 370 recenzji opublikowanych w „Rocznikach” świadczy o tym, że zespół redakcyjny miał dobre rozeznanie

\footnotetext{
${ }^{54}$ Tenże, Ks. Franciszek Ziegler, RTPNŚ 1934, t. 4, s. 250-254.
}

55 Tamże, s. 250.

56 E. Szramek, Ś. P. Adam Napieralski, RTPNŚ 1930, t. 2, s. 299-331.

57 W pierwszym tomie periodyku: P. Kuczka, Ś.p. Wiktoria z Żabińskich Niegolewska, RTPNŚ 1929, t. 1, s. 261-263 (W. Żabińksa-Niegolewska - działaczka społeczna, która swój księgozbiór i majątek przekazała dla Towarzystwa Przyjaciół Nauk na Śląsku), a w drugim: Ga[wlina], Śp. ks. biskup dr. Arkadiusz Lisiecki, RTPNŚ 1930, t. 2, s. 292-298 (A. Lisiecki - drugie biskup diecezji katowickiej, wybitny patrolog i uczony, doktor honoris causa Uniwersytetu Jagiellońskiego).

58 W. Olszewicz, Stanistaw Betza, RTPNŚ 1930, t. 2, s. 332-336 (S. Bełza - publicysta i podróżnik, organizator życia naukowego).

59 B. Parczewski ., S. Kobyliński, Kazimierz Czapla. Wiazanka wspomnień zebrana przez [...], RTPNŚ 1931, t. 3, s. 369-374 (K. Czapla - adwokat i obrońca w procesach politycznych, organizator pomocy dla uchodźców ze Śląska). Natomiast S. Kobyliński przygotował wspomnienie B. Parczewskiego, pierwszego prezesa TPNŚ i członka Rady Opiekuńczej: S. Kobyliński, Wspomnienie pośmiertne. Dr med. Bogusław Parczewski, RTPNŚ 1936, t. 5, s. 325-328.

60 K. Wolny, Śp. Stanisław Kobyliński, RTPNŚ 1938, t. 6, s. 329-333 (S. Kobyliński-adwokat, społecznik, działacz narodowy i członek Towarzystwa Naukowego Akademików Górnoślązaków).

${ }^{61}$ H. Hulok, Antoni Sieroń (1866-1936), RTPNŚ 1938, t. 6, s. 333-335 (A. Sieroń - wykwalifikowany ślusarz szerzący oświatę wśród ludu, założyciel Towarzystwa św. Alojzego). 
w najnowszej literaturze wydawanej na Śląsku i o Śląsku. Najwięcej recenzji wyszło - i tym razem - spod pióra E. Szramka ${ }^{62}$. O sposobie oceniania przez niego tekstów po latach napisano:

Pisząc krytyki o nowszych publikacjach z wielką życzliwością odnosił się Szramek do tych prac, które wnosiły do skarbnicy wiedzy i kultury polskiej coś nowego, możliwie oryginalnego, jako wynik dłuższych badań naukowych. Zaczynając od uwypuklenia pozytywnych wartości danego dzieła wytykał następnie błędy i uchybienia formalne i rzeczowe, jakie w danej pracy zauważył, ale nie czynił tego nigdy złośliwie, albo w przesadnie radykalny sposób, by pisarza, zwłaszcza początkującego, nie zniechęcić do dalszej pracy naukowej i pisarskiej ${ }^{63}$.

Podobny system oceny publikacji mieli i inni recenzenci, starając się wydobyć z omawianych dzieł wartości merytoryczne, wskazać na poprawność stylistyczną, jasny i przejrzysty przekaz. W każdym „Roczniku” pojawiało się kilkadziesiąt (np. od 31 w tomie drugim; do 95 w tomie szóstym) tekstów na temat nowych publikacji, poczynając od informacji sygnalnych lub kilkuzdaniowych omówień, a kończąc na kilkustronicowych krytycznych artykułach recenzyjnych. Wiele omówień wyszło spod pióra m.in. T. Dobrowolskiego ${ }^{64}$, J. Kudery ${ }^{65}$, R. Lutmana ${ }^{66}$, L. Musioła ${ }^{67}$, W. Ogrodzińskiego ${ }^{68}$, W. Olszewicza ${ }^{69}$, F. Popiołka ${ }^{70}$,

62 E. Szramek, O potrzebie tạczności pracy naukowej na obu Ślaskach, polskim i niemieckim, RTPNŚ 1929, t. 1, s. 227-229; tenże, Polski Stownik Biograficzny. Tom I (Abakanowicz - Beynart), Kraków 1935. Tom II (Beyzym - Brownsdorf), Kraków 1936. Tom III (Brożek Jan - ChwalciszewskiFranciszek) [...], RTPNŚ 1938, t. 6, s. 355-356.

63 H. Bednorz, J. Bańka, Życie i działalność ks. Emila Szramka..., s. 148.

${ }^{64}$ T. Dobrowolski, Dr. Jerzy Dobrzycki, Kościoly drewniane na Górnym Ślasku, Kraków 1926, RTPNŚ 1929, t. 1, s. 230-235; tenże, Prace naukowe poświęcone sztuce śląskiej, RTPNŚ 1934, t. 4, s. 293-299.

65 J. Kudera, Ludwik Musiot, Materiały do Dziejów Wielkich Katowic (1299-1799) z 5 planami i 13 rycinami. Katowice 1936, wydawnictwo Instytutu Śląskiego, stronic 220, RTPNŚ 1938, t. 6, s. $427-428$.

66 R. Lutman, Regionalna polska literatura historyczna na Górnym Ślasku 1922-1928, RTPNŚ 1929, t. 1, s. 208-221; tenże, „Der Oberschlesier”. Monatschrift fuer das heimatliche Kulturleben 1928, 1929, 1930 (I-V) hrsg. von Karl Sczodrok-Colonnowska, RTPNŚ 1930, t. 2, s. 378-380.

${ }_{67}$ L. Musioł, K. Prus, Z przeszłości miasta Mikołowa i jego okolicy. Mikołów - 1932 [...], RTPNŚ 1936, t. 5, s. 365-366; tenże, Herman Mojmir, Słownik niemieckiej gwary Wilamowic [...], RTPNŚ 1938, t. 6, s. 360-361.

68 W. Ogrodziński, Listy Józefa Lompy do J.I. Kraszewskiego z lat 1860-1862 wydat $i$ wstępem poprzedzit Kazimierz Dobrowolski, Katowice 1931 [...], RTPNŚ 1931, t. 3, s. 413-414; tenże Henryk Barycz, Ślazacy na Uniwersytecie Jagiellońskim w XV-XVIII w. Katowice (Wydawnictwa Instytutu Śląkiego) 1935 [...], RTPNŚ 1938, t. 6, s. 423-424.

69 W. Olszewicz, Stanisław Janicki, Budżet ślaski na rok 1928/29. Katowice 1928 [...], RTPNŚ 1929, t. 1, s. 244-245; tenże, Zaranie Śląskie. Kwartalnik. Cieszyn, Rocznik VI (1930) [...], RTPNŚ 1931, t. 3, s. 411-413.

70 F. Popiołek, Bobek Pawet, Przegląd dziejów chtopa polskiego, część I i II [...], RTPNŚ 1934, t. 4 , s. 315-317. 
Konstantego Prusa ${ }^{71}$, Ludwika Ręgorowicza ${ }^{72}$. Recenzjom poddawano niemal wszystkie prace, które ukazywały się na Śląsku i te, które omawiały zagadnienia Śląska a wydawane były w oficynach polskich i zagranicznych. Do przygotowania omówień angażowano nie tylko członków zespołu redakcyjnego, ale często zapraszano specjalistów z różnych dziedzin wiedzy, oczekując rzetelnej i merytorycznej oceny prac. Wśród recenzentów znaleźli się m.in.: Władysław Gębik - pedagog, pisarz, animator życia kulturalnego na Warmii i Mazurach, biolog; Emanuel Konstanty Imiela - prezes Śląskich Kół Śpiewaczych; Witold Mileski - prawnik, działacz na polu turystyki i ochrony przyrody; Stefan M. Stroiński dyrektor Instytutu Muzycznego w Katowicach.

Drugą część działu stanowiły liczne sprawozdania z aktywności członków TPNŚ. Relacjonowano wydarzenia im towarzyszące. O tym, jak ważne miejsce na łamach „Roczników” stanowily sprawozdania, dowodzi informacja ze wstępu do tomu szóstego:

Opóźnienie wydania niniejszego tomu [...] thumaczy się niespodziewanymi trudnościami na jakie napotkaliśmy w zbieraniu materiału do sprawozdawczej części Roczników, a właśnie ten dział jest nader ważny i zdajemy sobie sprawę z tego, że sumiennie opracowany, stanowić może prawdziwą «kopalnię» wiadomości o Śląsku ${ }^{73}$.

Stwierdzenie ilustruje rolę działu. Prezentowane sprawozdania dostarczają wielu cennych informacji z przebiegu zebrań, spotkań członków Towarzystwa lub dokumentują aktywność licznych społeczników. Relacje ze spotkań ukazywały się w formie szczegółowych omówień, obrazujących ówczesne problemy społeczne i gospodarcze oraz kulturalne i oświatowe. Ponadto sprawozdania zawierały informacje o wygłoszonych referatach i przeprowadzonych wykładach uwzględniając często streszczenia lub konspekty obrad.

\section{Z umysłowego życia Śląska kroniką aktywności kulturalnej i naukowej}

Zapowiedź tego działu jest szczególna pod względem treści i dość ciekawego skomponowania. Zamieszczany na końcu każdego „Rocznika” „zawiera zwięzłą, a możliwie dokładną kronikę życia umysłowego na Śląsku"74. Sama redakcja tak go opisywała: „Pod tym tytułem Towarzystwo Przyjaciół Nauk na Śląsku pragnie w swych Rocznikach zbierać informacje o wszelkich

71 K. Prus, Księga Pamiątkowa prywatnego z prawem publiczności polskiego gimnazjum realnego im. Juliusza Słowackiego w Orłowej, wydana z okazji 25-lecia istnienia zakładu. Orłowa 1934 [...], RTPNŚ 1934, t. 4, s. 313.

72 L.R. Ręgorowicz, Ludwik Musioł, Dzieje szkół parafialnych w dawnym dekanacie pszczyńskim. Katowice 1933 [...], RTPNŚ 1936, t. 5, s. 373-375.

73 [Wstęp], RTPNŚ 1938, t. 6, s. [5].

74 H. Bednorz, J. Bańka, Życie i działalność ks. Emila Szramka..., s. 138. 
dążeniach społeczeństwa naszego na Śląsku ku podniesieniu rodzimej kultury umysłowej i znajomości kraju" "75. Aktywność Towarzystwa i zaangażowanie członków na wielu płaszczyznach kulturalnych i społecznych, a także współpraca z licznymi instytucjami lokalnymi i ogólnopolskimi dały o sobie znać na łamach „Roczników”. W tej części periodyku (oprócz tomu piątego) zaprezentowano funkcjonowanie w środowisku lokalnym stowarzyszeń, kół, komitetów, związków i innych instytucji kultury, oświaty, nauki, gospodarki i administracji. W każdym tomie omówienie działań na rzecz upowszechniania kultury zajmowało około 100 stron tekstu ${ }^{76}$. Ze względu na obszerny i bogaty materiał źródłowy zawarty w tym dziale $\mathrm{w}$ artykule zasygnalizowano jedynie schemat podstawowej aktywności wymienionych instytucji. Materiał zaprezentowany w tej części „Roczników” wymaga szczegółowego i dogłębnego omówienia w kolejnym opracowaniu.

\section{Wieczory Dyskusyjne Towarzystwa Przyjaciół Nauk na Śląsu miejscem spotkania uczonych i badaczy}

Organizowane od 1935 r. wieczory dyskusyjne zostały udokumentowane w dwóch ostatnich tomach periodyku, a ich przebieg i merytoryczne dysputy zachowano w formie wykładów i sprawozdań z dyskusji. U genezy tych spotkań stało przekonanie, że:

Tym którzy pracują na polu nauki i zajmują się kwestiami wiedzy, okres dzisiejszy stawia specjalne zadania: wymaga by nauka nie zamykała się w granicach badań specjalnych, lecz by była zdolna podchodzić do żywych zjawisk kultury, oświetlać je, rozważać krytycznie i wydobywać z nich to, co w nich jest twórcze i pozytywne ${ }^{77}$.

Zakładano, że każde spotkanie poprzedzone będzie starannie przygotowanym wykładem,

na wcześniej ustalony i zaplanowany temat. Wykłady i debaty odbywały się kilka razy w roku w siedzibie TPNŚ. Uczestniczyło w nich od 50 do 100 osób ${ }^{78}$.

Uczestnikom wieczorów dyskusyjnych w pierwszym roku zaproponowano problematykę odnoszącą się do nauki i kultury. Na spotkaniach omawiane były takie zagadnienia jak: podstawy dyskursu o kulturze współczesnej, rola nauki we współczesnym poglądzie na świat, kryzys i upadek cywilizacji zachodniej,

\footnotetext{
75 Z umystowego życia Śląka, RTPNŚ 1929, t. 1, s. 264.

76 W celu przybliżenia zawartości działu $Z$ umystowego życia Ślaska można przeanalizować tematy poruszone w czwartym tomie „Roczników” gdzie omówiono instytucje w następującym porządku: Muzea; Archiwa; Biblioteki; Towarzystwa naukowe; Towarzystwa o celach literackich i artystycznych; Towarzystwa o charakterze zrzeszeń koleżeńskich; Instytucje i towarzystwa szerzące wiedzę zawodową i pokrewne; Inne towarzystwa.

${ }_{77}$ Wieczory Dyskusyjne Towarzystwa Przyjaciót Nauk na Ślasku, RTPNŚ 1936, t. 5, s. 300.

78 Tamże.
} 
postęp $\mathrm{w}$ nauce i kulturze ${ }^{79}$. Serię posiedzeń z tematyki regionalnej zainaugurował ks. E Szramek z wykładem O pojęcie Ślazaka ${ }^{80}$. Natomiast w drugim roku na plan pierwszy wysunęły się zagadnienia społeczne i gospodarcze. Wówczas analizowano współczesny kryzys ekonomiczny, omówiono spór uniwersalizmu i kolektywizmu w ujęciu historycznym, następnie problem uspołecznienia, rozpatrywano również zagadnienia ustroju korporacyjnego oraz zajmowano się zagadnieniami życia społecznego na Śląsku ${ }^{81}$.

\section{Podsumowanie}

Działalność TPNŚ była wyrazem zaangażowania jego członków w kreowanie polskości oraz w rozwój kultury i nauki na Śląsku. Najbardziej aktywną postacią był E. Szramek, wspierany przez grono członków zespołu redakcyjnego w osobach: J. Kudery, R. Lutmana, W. Ogrodzińskiego W. Olszewicza, F. Popiołka, K. Prusa. Byli to ludzie twórczy i aktywni, którzy rozumieli znaczenie istnienia Towarzystwa. W konkretny sposób przyczyniali się do jego merytorycznego rozwoju. Ważnym obszarem działalności Towarzystwa było wydawanie własnego periodyku, a w nim treści odnoszących się do śląskiej historii i kultury oraz zagadnień społecznych i gospodarczych tego regionu. Tym samym RTPNŚ „stały się prawdziwą kopalnią dokładnych i cennych wiadomości o regionie śląskim" "82. Są one żywym obrazem rozwijającego się życia umysłowego na Śląsku i wizytówką wszechstronnego zaangażowania ludzi wielu profesji i różnych stanów w rozwój nauki i kultury w lokalnym środowisku.

Liczne kontakty redaktora naczelnego w ogólnopolskim środowisku naukowym i udział w wielu gremiach sprawił, że w „Rocznikach” publikowali znani i cenieni naukowcy, badacze i specjaliści różnych dziedzin wiedzy. Interdyscyplinarność zagadnień i profesjonalizm autorów przyczyniły się do wysokiego poziom periodyku i mobilizacji zawłaszcza lokalnych badaczy, w podejmowaniu badań nad przeszłością Śląska. Kolejne tomy „Roczników” odzwierciedlały postawione w statucie zadanie: „Towarzystwo ma na celu ożywienie i popieranie umiejętności i sztuki polskiej na Śląsku, gromadzenie zabytków kultury wszelkiego rodzaju oraz krzewienia wśród ogółu zrozumienia dla swoich celów"83. Jego członkowie z odpowiedzialnością wywiązywali się z tych dekretacji. Analizując treść poszczególnych tomów i wczytując się w tematykę rozpraw warto przypomnieć stwierdzenie L. Brożka: „Każdy, kto interesuje

\footnotetext{
79 Tamże, s. 300-324.

80 Tamże, s. 323.

81 Wieczory Dyskusyjne Towarzystwa Przyjaciół Nauk na Śląsku, RTPNŚ 1938, t. 6, s. 305-328.

82 H. Bednorz, J. Bańka, Życie i działalność ks. Emila Szramka..., s. 138.

83 Statut Towarzystwa Przyjaciól Nauk na Śląsu..., s. 510.
} 
się ruchem kulturalnym i oświatowym na Śląsku, musi «Roczniki» koniecznie przestudiować" ${ }^{\prime}$. Dzięki ich lekturze, a zwłaszcza analizie merytorycznej zawartości, można dotrzeć do materiałów, które stanowią zachętę i inspirację do dalszych poszukiwań i badań.

\section{Bibliografia}

Akta wizytacji dekanatów bytomskiego i pszczyńskiego dokonanej w 1598 z polecenia Jerzego kardynała Radziwiłła, biskupa krakowskiego, wyd., wstępem i objaśnieniami zaopatrzył M. Wojtas, Katowice 1938, Fontes - Towarzystwo Przyjaciół Nauk na Śląsku, 3.

Bednorz H., Bańka J., Życie i działalność ks. Emila Szramka 1887-1942, Katowice 1966. Brożek L., Recenzje: Roczniki Towarzystwa Przyjaciót Nauk, „Zaranie Śląskie” 1931, t. 7, z. 2, s. 123-127.

Brożek L., Michejda O., Powojenna prasa polska na Ślasku Cieszyńskim, RTPNŚ 1934, t. 4, s. 217-230.

Bujak F., W sprawie organizacji studiów historycznych w Towarzystwie Przyjaciół Nauk na Ślasku, RTPNŚ" 1930, t. 2, s. 63-67.

Danysz-Fleszarowa R., Wspótczesne badania geologiczne na Górnym Śląsku, RTPNŚ 1931, t. 3, s. 356-368.

Dobrowolski T., Dr. Jerzy Dobrzycki, Kościoły drewniane na Górnym Śląku, Kraków 1926, RTPNŚ 1929, t. 1, s. 230-235.

Dobrowolski T., Działalność Muzeum Ślaskiego w Katowicach, RTPNŚ 1930, t. 2, s. 170 208.

Dobrowolski T., Oddziat sztuki i Muzeum Śląskiego w Katowicach, RTPNŚ 1929, t. 1, s. 90-109.

Dobrowolski T., Prace naukowe poświęcone sztuce ślaskiej, RTPNŚ 1934, t. 4, s. 293-299.

Dobrowolski T., Szramek E., Obraz Matki Bożej w Opolu oraz podobne mu gotyckie wizerunki Madonny z Dzieciatkiem, RTPNŚ 1938, t. 6, s. 203-222.

Duchowieństwo ślaskie XIII w. w walce o jedność państwowa z Polska, RTPNŚ 1929, t. 1, s. $162-184$.

Dziwoki J., Towarzystwo Przyjaciół Nauk na Śląsku. Kroniki śląskiego życia umysłowego, [w:] Katowice w kulturze pogranicza. Rola Katowic w kulturze i nauce, red. nauk. A. Barciak, Katowice 2012, s. 232-242.

Fazan M., Emil Szramek - organizator życia naukowego na Ślasku w okresie międzywojennym, [w:] Kronika Katowic. T. 4, Katowice 1993, s. 57-73.

Ga[wlina J.], Śp. ks. biskup dr. Arkadiusz Lisiecki, RTPNŚ 1930, t. 2, s. 292-298.

Gawlina J., Zasługi Ślązaków około starej Polski, RTPNŚ 1931, t. 3, s. 160-167.

${ }^{84}$ L. Brożek, Recenzje: Roczniki Towarzystwa Przyjaciół Nauk, „Zaranie Śląskie” 1931, z. 2, s. 127. 
Gładysz M., Polskie czasopisma dla dzieci i młodzieży na Śląsu, RTPNŚ 1931, t. 3, s. 303-321.

Grim E., Ks. Józef Londzin (8 II 1862-21 IV 1929). (Szkic biograficzny), RTPNŚ 1930, t. 2, s. 68-95.

Heska-Kwaśniewicz K., Ks. dr E. Szramek-życie i działalność (zarys), [w:] Ks. dr Emil Szramek. Działalność i dzieła. Materiały posesyjne, red. J. Malicki i J. Śliwiok, Katowice 1994, s. 9-14.

Historia residentiae et templi Societatis Jesu Piekarii (1678-1716), Katowice 1932, Fontes - Towarzystwo Przyjaciół Nauk na Śląsku, 1.

Hulok H., Antoni Sieroń (1866-1936), RTPNŚ 1938, t. 6, s. 333-335.

Jabłońska W., Biblioteka Polska w Rumunii jej wpływ na powstanie Towarzystwa Przyjaciół Nauk na Ślasku, ,Roczniki Biblioteczne” 1960, t. 4, s. 477-520.

Janota W., Górnośląskie Towarzystwo Literackie (1892-1920), Katowice 2002.

Kobyliński S., Wspomnienie pośmiertne. Dr med. Bogusław Parczewski, RTPNŚ 1936, t. 5, s. 325-328.

Koziołek A., Knurów i Krywałd. Kronika na tle historii ziemi gliwickiej, Katowice 1937, Monografie Towarzystwa Przyjaciół Nauk na Śląsku, 4.

Księga protokołów konwentów pastorskich ziemi pszczyńskiej (1588-1628), oprac. J. Bańka, Katowice 1938, Fontes - Towarzystwo Przyjaciół Nauk na Śląsku, 4.

Kuczka P., Ś.p. Wiktoria z Żabińskich Niegolewska, RTPNŚ 1929, t. 1, s. 261-263.

Kudera J., Ludwik Musiot, Materiaty do Dziejów Wielkich Katowic (1299-1799) z 5 planami i 13 rycinami. Katowice 1936, wydawnictwo Instytutu Ślaskiego, stronic 220, RTPNŚ 1938, t. 6, s. 427-428.

Londzin J., Kościoły drewniane na Śląsku Cieszyńskim, RTPNŚ 1929, t. 1, s. 19-35.

Lutman R., „Der Oberschlesier”. Monatschrift fuer das heimatliche Kulturleben 1928, 1929, 1930 (I-V) hrsg. von Karl Sczodrok-Colonnowska, RTPNŚ 1930, t. 2, s. 378380.

Lutman R., Biblioteka Sejmu Ślaskiego w Katowicach, RTPNŚ 1930, t. 2, s. 209-213.

Lutman R., Regionalna Polska literatura historyczna na Górnym Ślasku, RTPNŚ 1929, t. 1, s. 208-221.

Łuka J., Z dziejów Towarzystwa Przyjaciót Nauk na Ślasku, RTPNŚ 1929, t. 1, s. 1-18.

Musioł L., Herman Mojmir, Stownik niemieckiej gwary Wilamowic [...], RTPNŚ 1938, t. 6, s. 360-361.

Musioł L., K. Prus, Z przeszłości miasta Mikołowa i jego okolicy. Mikołów - 1932 [...], RTPNŚ 1936, t. 5, s. 365-366.

Musioł L., Pszczyna. Monografia historyczna. Katowice 1936, Monografie Towarzystwa Przyjaciół Nauk na Śląsku, 3.

Myszor J., Dlaczego zginąt ks. Emil Szramek, [w:] Victor-quia Victima. Ksiadz Emil Szramek (1887-1942). Praca zbiorowa, pod red. E. Szczotoka i A. Liskowackiej, Katowice 1996, s. 59-68. 
Myszor J., Ks. Emil Szramek-kapłan diecezji wrocławskiej (1911-1922), „Ziemia Śląska” 2001, t. 5, s.73-80.

Myszor J., Stuga Boży ks. Emil Szramek - proces beatyfikacyjny Męczenników II wojny światowej. Nowe pytania i odpowiedzi. Edycja tekstów źródłowych, „Śląskie Studia Historyczno-Teologiczne" 1997, t. 30, s. 249-271.

Myszor J., Stuga Boży ks. Emil Szramek (1887-1942), [w:] Męczennicy za wiarę 19391945, red. W.M. Moroz, A. Datko, Warszawa 1996, s. 95-100.

Nowe oblicza bł. Emila Szramka, pod red. K. Heskiej-Kwaśniewicz i J. Myszora, Katowice 2003.

Ogrodziński W., Antoni Bednarski, RTPNŚ 1931, t. 3, s. 384-385.

Ogrodziński W., Henryk Barycz, Ślązacy na Uniwersytecie Jagiellońskim w XV-XVIII w. Katowice (Wydawnictwa Instytutu Śląskiego) 1935 [...], RTPNŚ 1938, t. 6, s. 423-424.

Ogrodziński W., Ks. dr Jan Chrząszcz, RTPNŚ 1929, t. 1, s. 258-261.

Ogrodziński W., Ks. Franciszek Ziegler, RTPNŚ 1934, t. 4, s. 250-254.

Ogrodziński W., Ks. proboszcz Józef Gregor, RTPNŚ 1929, t. 1, s. 254-258.

Ogrodziński W., Ks. Wiktor Loss, RTPNŚ 1934, t. 4, s. 241-248.

Ogrodziński W., Listy Józefa Lompy do J.I. Kraszewskiego z lat 1860-1862 wydat i wstępem poprzedził Kazimierz Dobrowolski, Katowice 1931 [...], RTPNŚ 1931, t. 3, s. 413-414.

Ogrodziński W., O. Euzebiusz Franc. Stateczny przedstawiciel „Młodej Polski” w prozie Górnośląskiej, RTPNŚ 1938, t. 6, s. 7-202.

Olszewicz W., Stanisław Bełza, RTPNŚ 1930, t. 2, s. 332-336.

Olszewicz W., Stanisław Janicki, Budżet śląsi na rok 1928/29. Katowice 1928 [...], RTPNŚ 1929, t. 1, s. 244-245.

Olszewicz W., Zaranie Śląskie. Kwartalnik. Cieszyn, Rocznik VI (1930) [...], RTPNŚ 1931, t. 3, s. 411-413.

Olszewicz W., Ślask i Battyk, RTPNŚ 1929, t. 1, s. 110-124.

Ostaszewska D., Wkład księdza Emila Szramka w rozwój stylu prozy naukowej na Śląsku w latach 1922-1939, [w:] Książka Polska na Śląsku 1922-1945. Zarys problematyki, pod red. M. Pawłowiczowej, Katowice 1994, s. 136-143.

Pampuch P., Usamowolnienie i uwłaszczenie polskich chłopów górnośląskich, RTPNŚ 1929 , t. 1, s. 36-57.

Parczewski B., Kobyliński S., Kazimierz Czapla. Wiąanka wspomnień zebrana przez [...], RTPNŚ 1931, R. 3, s. 369-374.

Popiołek F., Bobek Pawet, Przegląd dziejów chłopa polskiego, część I i II [...], RTPNŚ 1934, t. 4, s. 315-317.

Popiołek F., Kamienica Demlowska, siedziba Muzeum Miejskiego w Cieszynie, RTPNŚ 1931, t. 3, s. 348-350.

Popiołek F., Materiały do historii Śląsk $w$ zbiorach cieszyńskich, RTPNŚ 1931, t. 3, s. 343-347.

Popiołek F., Zbiory cieszyńskie, RTPNŚ 1930, t. 2, s. 214-225. 
Powiat świętochtowicki. Monografia, oprac. przez komitet red. pod przewod. starosty świętochłowickiego T. Szalińskiego, Katowice 1931, Monografie Towarzystwa Przyjaciół Nauk na Śląsku, 1.

Prus K., Księga Pamiatkowa prywatnego z prawem publiczności polskiego gimnazjum realnego im. Juliusza Słowackiego w Orłowej, wydana z okazji 25-lecia istnienia zakładu. Orłowa 1934 [...], RTPNŚ 1934, t. 4, s. 313.

Prus K., Z przeszłości Mikołowa i jego okolicy, Mikołów 1932, Monografie Towarzystwa Przyjaciół Nauk na Śląsku, 2.

Pyka H., Mecenat artystyczny Księdza Emila Szramka w Parafii Mariackiej w Katowicach, „Śląskie Studia Historyczno-Teologiczne” 1992-1993, t. 25-26, s. 307-316.

Reiter J., Towarzystwo Oświaty na Ślasku im. św. Jacka, Opole 1968.

Ręgorowicz L.R., Ludwik Musioł, Dzieje szkół parafialnych $w$ dawnym dekanacie pszczyńskim. Katowice 1933 [...], RTPNŚ 1936, t. 5, s. 373-375.

Sahanek W., Spór o dobra cieszyńskie, RTPNŚ 1931, t. 3, s. 168-254.

Sprawozdanie Towarzystwa Przyjaciót Nauk na Śląsu za rok 1929, RTPNŚ 1930, t. 2, s. 415-418.

Staropolskie teksty z protokolarza miasta Woźniki w województwie śląskim 1521-1750, wyd. i wstępem opatrzył L. Musioł, Katowice 1936, Fontes - Towarzystwo Przyjaciół Nauk na Śląsku, 2.

Statut Towarzystwa Przyjaciół Nauk na Ślasku, RTPNŚ 1938, t. 6, s. 510-516.

Szanecka A., Pasje turystyczne ks. Emila Szramka, „Wiadomości Archidiecezjalne” 1996, nr 8, s. 382-384.

Szramek E., Dr med. Józef Rostek. Życiorys a zarazem przyczynek dziejów narodowego odrodzenia Śląska, RTPNŚ 1930, t. 2, s. 142-169.

Szramek E., Ks. Aleksander Skowroński. Obraz życia i pracy na tle problematyki kresów zachodnich, RTPNŚ 1936, t. 5, s. 7-214.

Szramek E., Ks. Jan Kapica. Życiorys a zarazem fragment historii Górnego Śląska, RTPNŚ 1931, t. 3, s. 1-86.

Szramek E., Ks. Norbert Bonczyk. Homer górnośląski i poeta walki kulturalnej. Studium historyczno-literackie, w 50 lat po pierwszym wydaniu ,Starego Kościoła Miechowskiego”, RTPNŚ 1930, t. 2, s. 1-62.

Szramek E., O potrzebie łączności pracy naukowej na obu Śląskach, polskim i niemieckim, RTPNŚ 1929, t. 1, s. 227-229.

Szramek E., Organiczny związek urzędów szkolnych z kościelnymi w historycznym rozwoju na Śląsku, RTPNŚ 1929, t. 1, s. 58-68.

Szramek E., Polski Słownik Biograficzny. Tom I (Abakanowicz-Beynart), Kraków 1935. Tom II (Beyzym - Brownsdorf), Kraków 1936. Tom III (Brożek Jan - ChwalciszewskiFranciszek) [...], RTPNŚ 1938, t. 6, s. 355-356.

Szramek E., Szczegółowy (częściowy) wykaz dziesięcin archidiakona opolskiego z roku 1464, RTPNŚ 1930, t. 2, s. 271-278.

Szramek E., Ś. P. Adam Napieralski, RTPNŚ 1930, t. 2, s. 299-331. 
Szramek E., Śląsk jako problem socjologiczny, RTPNŚ 1934, t. 4, s. 22-95.

Szramek E., Ks. Franciszek Ziegler, RTPNŚ 1934, t. 4, s. 250-254.

Tałuć K., Ks. dr Emil Szramek jako redaktor i autor prac publikowanych na łamach „, Gtosów znad Odry” i „Roczników Towarzystwa Przyjaciót Nauk na Śląku”, „Annales Silesiae" 1998, t. 28, s. 43-58.

Tofilska J., Parafia Mariacka w Katowicach. Historia jak witraż, Katowice 2010.

Walis S., O tańcach górnośląskich, RTPNŚ 1929, t. 1, s. 185-198.

Warcholik S., Duchowieństwo śląkie XIII w. w walce o jedność państwowa z Polska, RTPNŚ 1929, t. 1, s. 162-184.

Warcholik S., Polityka śląska Kazimierza Wielkiego w latach 1333-1339, RTPNŚ 1930, t. 2, s. 96-118.

Wędrynia. Jedna ze wsi beskidzkich w pow. cieszyńskim. Jej dzieje i źródła historyczne z Archiwum Zamkowego w Cieszynie, wyd. i wstępem opatrzył F. Popiołek, Katowice 1938, Fontes - Towarzystwo Przyjaciół Nauk na Śląsku, 5.

Wieczory Dyskusyjne Towarzystwa Przyjaciół Nauk na Śląku, RTPNŚ 1936, t. 5, s. 300324.

Wieczory Dyskusyjne Towarzystwa Przyjaciót Nauk na Ślasku, RTPNŚ 1938, t. 6, s. $305-$ 328.

Wolny K., Śp. Stanisław Kobyliński, RTPNŚ 1938, t. 6, s. 329-333.

[Wstęp], RTPNŚ 1929, t. 1, s. [5].

[Wstęp], RTPNŚ 1931, t. 3, s. [5-6].

[Wstęp], RTPNŚ 1938, t. 6, s. [5-6].

Z umysłowego życia Śląska, RTPNŚ 1929, t. 1, s. 264-295.

Żółtaszek J., Dzikie kopalnictwo węgla na Górnym Śląsku, RTPNŚ 1936, t. 5, s. 282-299. 
